\title{
Modelling the response in streamflow to increased forestry plantations
}

\author{
$\underline{\text { K.M. Barlow }}^{\text {ac }}$, A. Weeks ${ }^{\text {ac }}$ and B. Christy ${ }^{\text {abc }}$ \\ ${ }^{a}$ Future Farming Systems Research, Department of Environment and Primary Industries, 124 Chiltern \\ Valley Road, Rutherglen, Victoria 3685 AUSTRALIA. \\ ${ }^{b}$ Future Farm Industries CRC, University of Western Australia, AUSTRALIA \\ ${ }^{c}$ eWater CRC, University of Canberra, ACT AUSTRALIA \\ Email: kirsten.barlow@depi.vic.gov.au
}

\begin{abstract}
Plantation forestry is an important land use in Australia which has the potential to reduce water yields compared with existing agricultural use. However, because of the biophysical complexity of landscapes, the hydrological impact of plantation expansion will vary between catchments and between locations within catchments. This paper investigates whether incorporating the history of plantation expansion in a catchment improves the prediction of streamflow by capturing the lag in catchment water balance and streamflow response in response to changes in plantation area and age.
\end{abstract}

The study area for this project was the Glenelg Hopkins Region, South West Victoria, Australia; specifically the Crawford River, Eumeralla River and Darlot Creek. These catchments were selected as they were historically dominated by pasture based agricultural systems $(>60 \%)$ and had seen a significant increase in plantation forestry over the last 10-15 years. The plantation history was estimated using the best available data, including an analysis of plantation data supplied by Green Triangle plantation growers as well as data from miscellaneous sources such as aerial photography and vegetation cover data. The majority of plantations in the Darlot Creek ( $<15 \%$ catchment) and Eumeralla River ( $<15 \%$ catchment) catchments were established in 2000-2005, while in the Crawford River ( 30\% catchment) small areas of radiata pine plantation were established between 1960-1970 and blue gum plantations were established after 1995.

The potential impacts of plantation forests on streamflow were investigated using the Catchment Analysis Tool (CAT, DEPI Victoria). The CAT was selected to investigate plantation forestry, due to its ability to incorporate land use change history over time within a spatial context to predict catchment water use and streamflow. In this study two component models, CAT1D and CATNode, were used to link paddock-scale land use, soils, topography and climate data to catchment-scale groundwater systems and streamflow at the gauge. The CATNode model was calibrated using the Plantation History land use layer as the best available history of land use and land use change in the catchment. To investigate whether the inclusion of plantation history improved the prediction of streamflow compared to the Static land use, the calibrated model was rerun using the Static land use layer and the difference in cumulative flow was analysed.

CAT was able to provide an adequate streamflow prediction over time (monthly Coefficient of Efficiency $>0.7$ ). In addition the incorporation of timing and pattern of plantation history demonstrated a small, consistent improvement in temporal streamflow predictions in each of the three catchments, with the results demonstrating a delayed pattern (4-5 years) in streamflow response consistent with the timing and pattern of plantation history. Due to the hydrological complexity of landscapes, the impact on streamflow of future plantation expansion will vary across the landscape; CAT presents a valuable tool for investigating the potential impacts of future plantations.

Keywords: Forestry, Afforestation, CAT, Water yield, Land use change 
Barlow et al., Capturing the lag and response in streamflow due to plantation history.

\section{INTRODUCTION}

Plantation forestry is an important land use in Australia which has the potential to provide many commercial and environmental benefits. However, it is well established that conversion of agricultural lands to plantations has the potential to reduce water yields (eg. Brown et al., 2007). Due to the complexity of landscapes, the hydrological impact of plantation expansion will vary between catchments and between locations within catchments.

\subsection{The Study Area}

The study area for this paper was the Darlot Creek, Eumeralla River and Crawford River Catchments in the Glenelg Hopkins Region (Figure 1). The three catchments will be referred to as the DEC Catchments when discussing them collectively. These catchments were selected as they were all historically dominated by pasture based agricultural systems $(>60 \%)$ and have seen a significant increase in plantation forestry over the last 10-15 years.

The Crawford River is approximately $82 \mathrm{~km}$ long running south-west through the catchment. The geomorphology of the

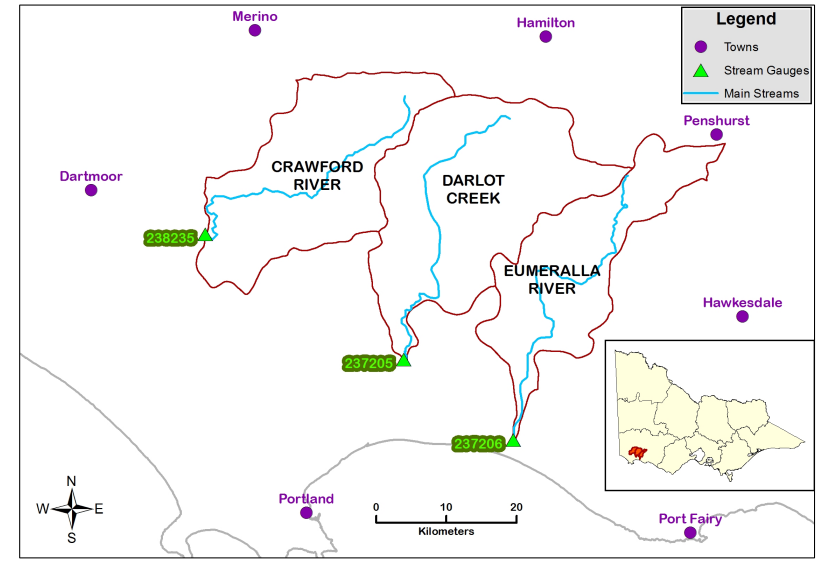

Figure 1. Location of the DEC Catchments, Victoria.

Crawford River Catchment is dominated by the South West Sands in the west of the catchment and Basalt Plains in the east. There is a substantial area of crown land in the sub-catchment that has not been cleared including State Forests. Land use in the catchment is now predominantly forestry based with blue gum and pine production; however there are still areas of sheep and cattle grazing within the catchment.

Darlot Creek is approximately $51 \mathrm{~km}$ long running south into the Fitzroy River. The geomorphology of the region is predominantly Basalt Plains, South West Sands and Stoney Rises. The catchment includes the Mt Napier State Park, Mt Eccles National Park, Condah swamps and Lake Condah. Land use within the Darlot Creek catchment includes grazing (beef, sheep and dairy) and forestry production.

The Eumeralla River is approximately $90 \mathrm{~km}$ long flowing south through the catchment to Lake Yambuk at the coast (outside the study area). There are a number of tributaries flowing into the Eumeralla including Back Creek, Middle Creek, Gorrie Swamp, Snakey Creek and Deep Creek. Similar to the Darlot Creek catchment the geomorphology of the region is predominantly Basalt Plains, South West Sands and Stoney Rises.

\subsection{Objectives}

This paper used the Catchment Analysis Tool (DPI, 2009) to investigate whether incorporating the history of land-use change and plantation expansion in a catchment improved the prediction of streamflow by capturing the subsequent decrease in streamflow.

\section{METHODOLOGY}

\subsection{The Catchment Analysis Tool (CAT)}

The Catchment Analysis Tool (CAT, Version 8.1.1) was selected to investigate plantation forestry, due to its ability to incorporate land use change history over time within a spatial context to predict catchment water use and streamflow (DPI, 2009; Weeks et al., 2008). In this study two component models, CAT1D and CATNode, were used to link paddock-scale land use, soils, topography and climate data to catchment-scale groundwater systems and streamflow. CAT1D utilised a suite of contemporary one dimensional models (DPI, 2009) including a forest growth model (3-PG: Landsberg and Waring, 1997) to determine paddock scale daily catchment water use, quick flow and recharge across landscapes. CATNode, a lumped surfacegroundwater model (detailed in Cheng et al., 2013), was then used to model catchment scale streamflow at the gauge. The CAT modelling suite was selected for two main reasons, namely the use of:

- CAT1D to determine the quickflow component of the model provided a biophysical prediction of quickflow or surface runoff that did not need to be calibrated, was spatially explicit and linked to land 
Barlow et al., Capturing the lag and response in streamflow due to plantation history.

uses which could change over time such as the rotation of crops or the conversion of pasture to plantations.

- CATNode was selected as a lumped surface-groundwater model which used non-physical coefficients to define water movement and was readily calibrated using available monitored stream gauge information.

\subsection{Overview of Modelling Approach}

The CAT model was applied across the DEC catchments (Figure 1) over the period 1/1/1957 to 31/12/2008. Model simulation was conducted on $100 \mathrm{~m}$ grid cells which each had unique a combination of climate, soils, topography and land use history. The main steps in this project were to:

- Collate required input data for the study area including climate, soils, topography from available data sources (Weeks et al., 2008), as well as land use and streamflow detailed below;

- Run CAT1D, the one-dimensional water balance model to produce estimates of daily water balance outputs (eg. evapotranspiration, runoff, subsurface lateral flow and recharge);

- Aggregate daily water balance outputs to a monthly time step to provide inputs for CATNode;

- Calibrate CATNode and analyse the modelled streamflow response.

\subsection{Land use}

Two land use data sets were created for this paper which included water, crop, pasture and urban uses as well as native and plantation trees:

- The "Static Land Use" (Figure 2a), incorporated the defined land practices from the Australia Land Use Mapping (ALUM) classification Version 5 (BRS, 2001), with spatial information sourced between the years 2000-2002. This land use was held constant in the CAT1D model over the modelling period.
Table 1. Summary of plantation history for the three DEC catchments.

\begin{tabular}{cccc}
\hline & \multicolumn{2}{c}{$\begin{array}{c}\text { Percentage of catchment covered by } \\
\text { plantations }\end{array}$} \\
\cline { 2 - 4 } Year & Eumeralla & Darlot & Crawford \\
\hline 1975 & 0 & 0.1 & 0.2 \\
1985 & 0 & 0.27 & 2.1 \\
1995 & 1.5 & 1.0 & 4.9 \\
2000 & 10.0 & 9.7 & 26.0 \\
2005 & 11.4 & 11.8 & 31.4 \\
\hline
\end{tabular}

- The "Plantation History" (Figure 2b), incorporated a spatial representation of the plantation forest areas in 2009. This was combined with an estimate of age class distribution (Table 1), based on an analysis of plantation data supplied by Green Triangle plantation growers and supplemented by data from miscellaneous sources such as aerial photography interpretation and vegetation cover data (pers. comm. Don McGuire, ForestrySA, Mt Gambier). The temporal and spatial data was combined within CAT to provide details on the management of each $100 \mathrm{~m}$ grid, especially the conversion from pasture to plantation systems.

a)

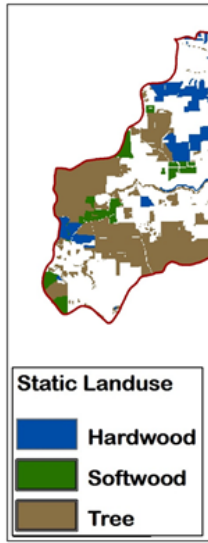

Figure 2. Land use for the DEC catchments, (a) Static Land Use, and (b) Plantation History.

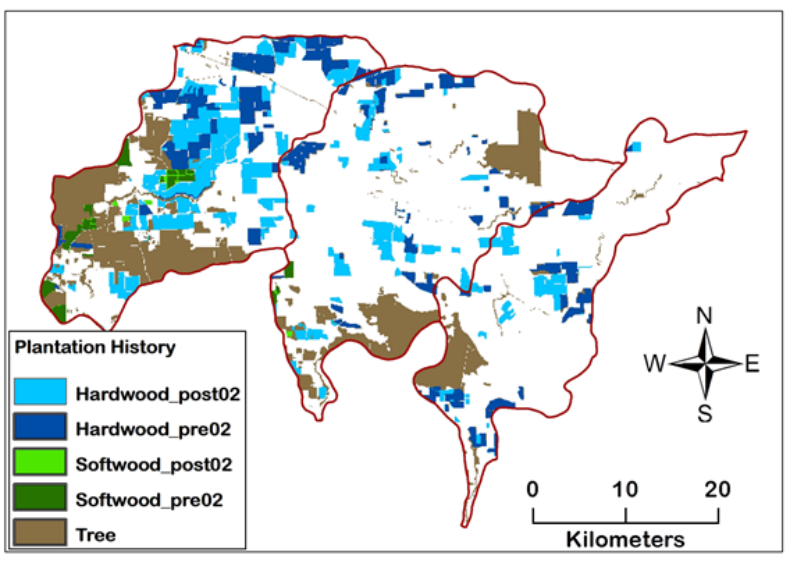

b) 
Barlow et al., Capturing the lag and response in streamflow due to plantation history.

\subsection{Calibration}

Daily streamflow data for the three stream gauges in the DEC catchment were obtained from the Victorian Water Resources Data Warehouse (VWQMN, 2009) (Table 2). The baseflow contribution was estimated using an automated digital filter technique (Arnold and Allen, 1999) to separate the daily baseflow data. The daily stream gauge data was then averaged on a monthly time-step to match the time scale of the CATNode model.

CATNode was

Table 2. Summary of streamflow data for the DEC catchments, Victoria.

run from 1957 to

2008 using the

"Plantation

History" land use

layer (Figure 2b).

The period 1957-

\begin{tabular}{lcccc}
\hline Gauge Number & \multicolumn{2}{c}{ Streamflow data } & $\begin{array}{c}\text { Mean annual } \\
\text { Streamflow } \\
(\mathrm{mm})\end{array}$ & $\begin{array}{c}\text { Mean annual } \\
\text { base flow } \\
(\mathrm{mm})\end{array}$ \\
\hline Darlot- 237205 & $7 / 11 / 1969$ & $30 / 09 / 2009$ & 80 & 58 \\
Eumeralla- 237206 & $20 / 11 / 1973$ & $11 / 11 / 2009$ & 61 & 33 \\
Crawford- 238235 & $26 / 05 / 1970$ & $12 / 11 / 2009$ & 72 & 29 \\
\hline
\end{tabular}

1974 was used as a warm-up period to ensure water stores had a chance to reach a state of equilibrium. The CATNode model was calibrated for the period 1975-2008 against measured streamflow and baseflow on a monthly time-step using an automated constrained non-linear optimizer within the CAT modelling framework.

Two key objective functions were used in the calibration and analysis of the DEC catchments, namely the Nash Sutcliffe Coefficient of Efficiency (CoE; Nash and Sutcliffe, 1970) and difference in cumulative flow. $\mathrm{CoE}$, calculated on a monthly basis, was used to assess the predictive power of hydrological models. It is defined as:

$$
C o E=1-\frac{\sum_{t=1}^{T}\left(Q_{o}^{t}-Q_{m}^{t}\right)^{2}}{\sum_{t=1}^{T}\left(Q_{o}^{t}-\overline{Q_{o}}\right)^{2}}
$$

where $Q_{o}^{t}$ is observed discharge, $Q_{m}^{t}$ is modelled discharge at time $t \bar{Q}_{o}$ is the average observed discharge in the calibration period and $T$ is the number of observation points. The CoE can range from $-\infty$ to 1 , where the authors defined a $\mathrm{CoE}$ of $0.6-0.79$ as satisfactory and a $\mathrm{CoE}$ of 0.8 or higher as providing a good representation of streamflow at the gauge.

The percentage difference in cumulative flow was defined as:

$$
\text { CumFlow } \%=\left(1-\frac{\sum_{t=1}^{T}\left(Q_{o}^{t}\right)}{\sum_{t=1}^{T}\left(Q_{m}^{t}\right)}\right) \times 100
$$

\section{RESULTS}

Streamflow, quick-flow and base-flow were predicted for the three DEC catchments over the period 19752008 using the "Plantation History" land use as the best available land use data. Figure 3 shows the results for the Crawford River Catchment, while Table 3 provides a summary of the streamflow analysis for the three catchments.

Table 3. Summary of the Coefficient of Efficiency and Streamflow predictions for the DEC catchments, Victoria.

\begin{tabular}{lcccccc} 
& \multicolumn{3}{c}{ Coefficient of Efficiency } & \multicolumn{2}{c}{$\begin{array}{c}\text { Mean annual streamflow } \\
(\mathrm{mm})\end{array}$} & CumFlow\% \\
Catchment & Streamflow & Base flow & Quick flow & Measured & Predicted & \\
\hline Darlot & 0.64 & 0.67 & 0.66 & 79.8 & 79.5 & $<1 \%$ \\
Eumeralla & 0.70 & 0.67 & 0.80 & 61.1 & 67.7 & $10.8 \%$ \\
Crawford & 0.78 & 0.79 & 0.67 & 71.6 & 81.1 & $13.2 \%$ \\
\hline
\end{tabular}

Over the 1975-2008 period CATNode provided an acceptable prediction of streamflow (Table 3) for all of the DEC catchments, although it slightly overestimated total streamflow in the Eumeralla and Crawford River catchments (Table 3). The prediction of streamflow for the Crawford River (Figure 3) shows a generally good prediction of magnitude and timing of peak flow events (Figure 3b). Of the DEC catchments, Darlot Creek had the poorest fit between observed and predicted streamflow with CoEs less than 0.7 for streamflow as well as base flow and quick flow. However, with less than $1 \%$ difference in cumulative flow, the results suggest that the variation is in the pathways and timing of monthly flow rather than the total 
Barlow et al., Capturing the lag and response in streamflow due to plantation history.

volume of flow. In the Darlot Creek catchment the timing of streamflow was affected by the Condah Swamp (a series of wetlands) and Lake Condah which are at the lower end of the catchment.
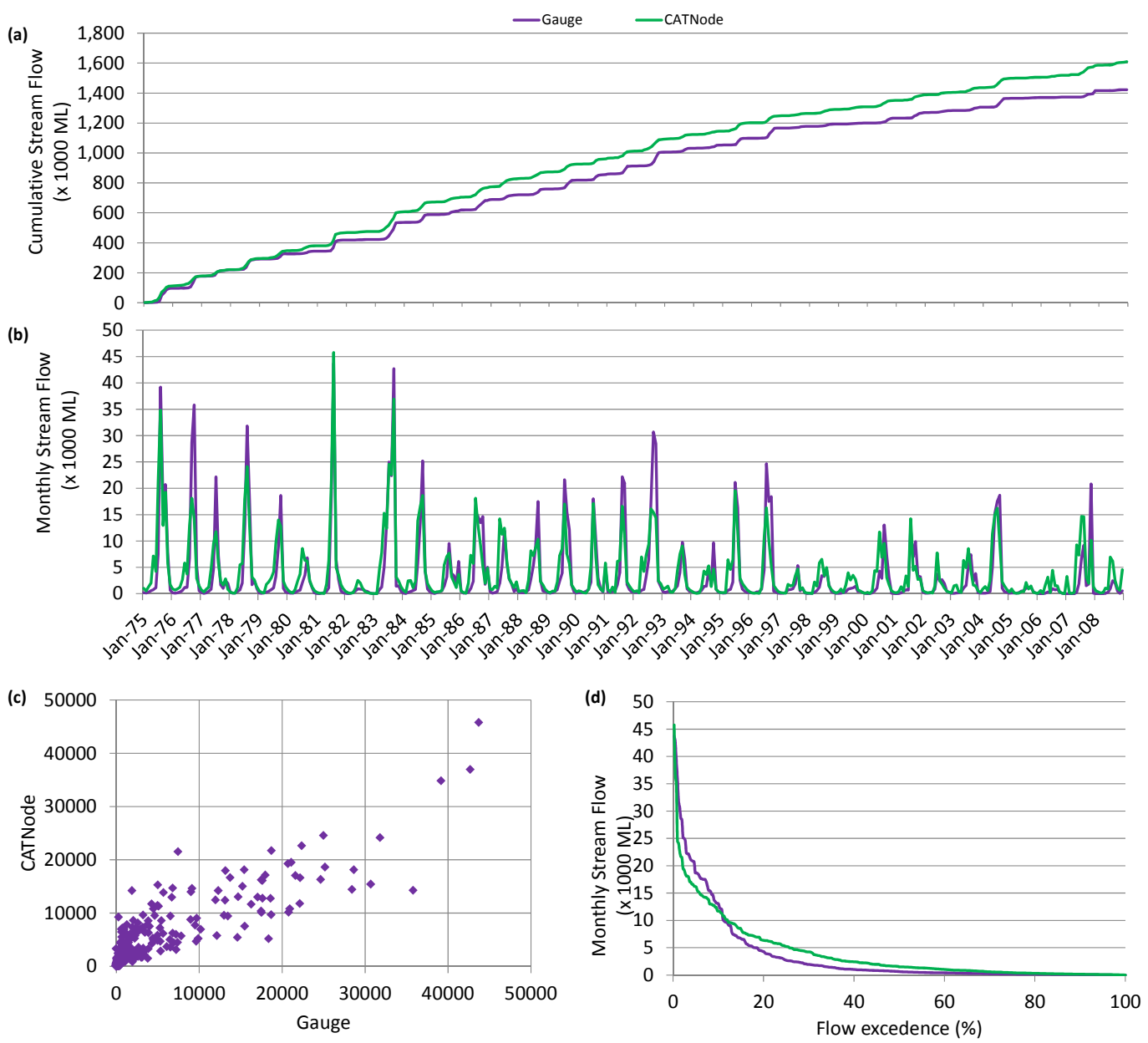

Figure 3. Observed and simulated streamflow (ML/month) for the Crawford River catchment using the Plantation History Land Use layer from 1975-2008. Showing the (a) cumulative flow, (b) monthly flow, (c) comparison of modelled and observed monthly discharge volume, and (d) flow duration curve.

The CATNode model for the DEC catchments was calibrated using the "Plantation History" land use layer (Figure 2b) as it represented the best available history of land use and land use change in the catchments. To investigate the difference in predicted streamflow as a result of land use change history, CAT was run using the calibrated CATNode parameters combined with the "Static Land Use" layer (Figure 2a). There were only minor differences in the predicted streamflow between the two different land use layers. This was not all that surprising given that the majority of plantations across the DEC catchments were established after 2000 restricting the potential for plantations to impact on streamflow.

However, there were differences in the cumulative flow between the Static and Plantation History land use scenarios demonstrating the increasing impact of plantations as they grow on streamflow (Figure 4). Across the three catchments there is a reduction in streamflow over time with the introduction of plantation history into the CAT model. In both the Darlot Creek and Eumeralla River catchments this is seen as a stepped change in cumulative flow approximately 5 years after plantation establishment (Figure $4 \mathrm{a}$ and $4 \mathrm{~b}$ ). This is consistent with previous research into the effect of afforestation on streamflow (eg. Scott and Lesch, 1997; Scott and Prinsloo, 2008). However, in Darlot creek, the total difference in cumulative flow over the 34 year modelling period was less than $0.3 \%$, which was not surprising given that the Plantations were less than $1 \%$ of the land use for the majority of the modelling period. But, when cumulative flow for Darlot creek was calculated from January 2000 to December 2008 the difference in cumulative flow was $1.5 \%$ due to the larger proportion of plantations affecting streamflow throughout the period; this difference would be expected to increase over time. 
Barlow et al., Capturing the lag and response in streamflow due to plantation history.

a)
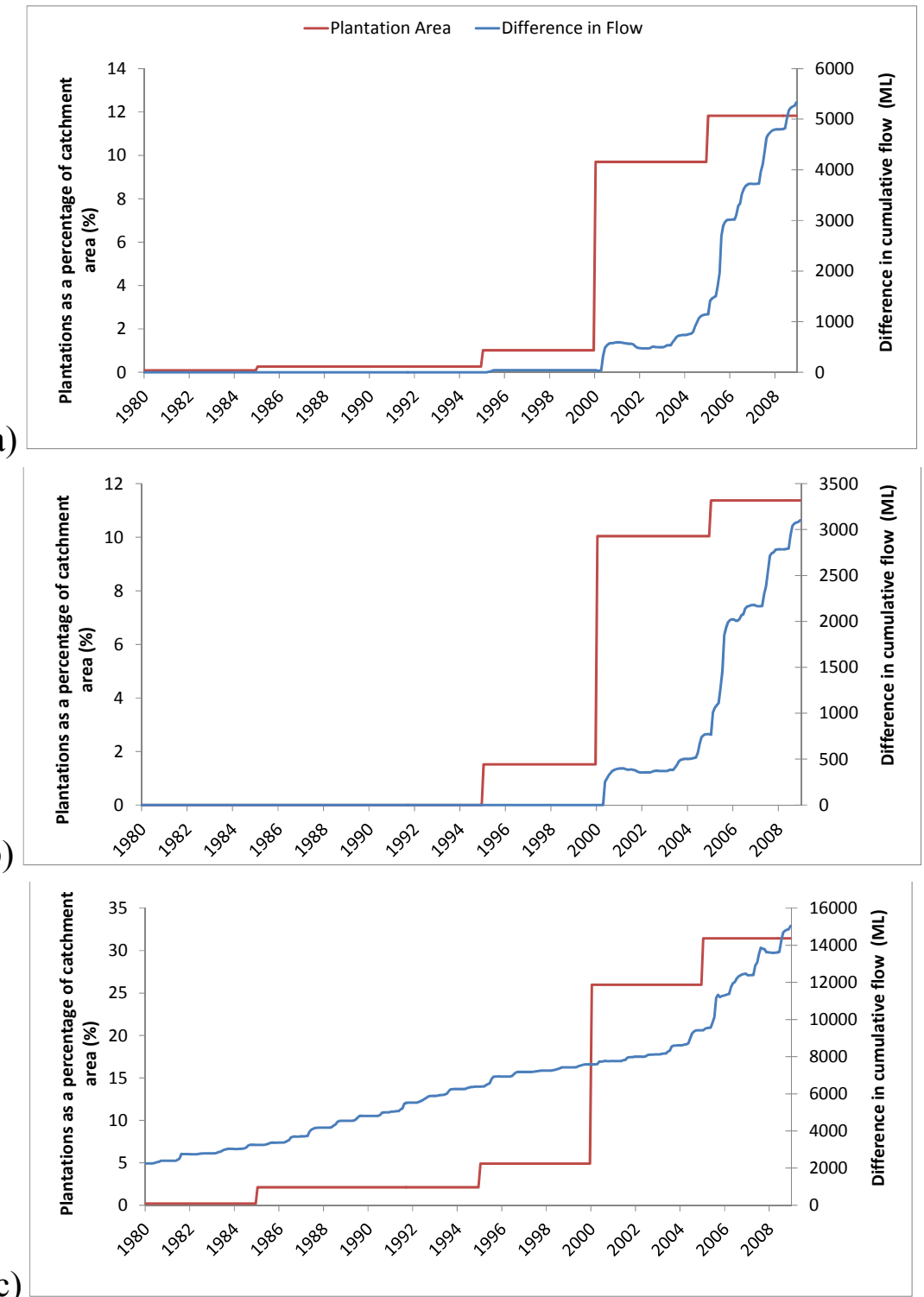

Figure 4. The difference in cumulative flow (ML) between streamflow predicted using the "Static Land Use in 2000" and the "Plantation History" in relation to the percentage of plantation timber in the (a) Darlot Creek, (b) Eumeralla River, and (c) Crawford River catchments.

In the Crawford River catchment, the impact of plantations across the catchment is not as clear although the response can still be observed (Figure 4c). There was a difference between the cumulative flow of the Static and Plantation History scenarios, with a clear step change in flow observed in 2005, approximately 5 years after the largest step in plantation area. The lack of a stepped response in streamflow prior to 2005 in the Crawford River catchment may be due to the significant proportion of trees (non-plantation) within the catchment buffering the streamflow response to small increases in plantation area.

\section{DISCUSSION AND CONCLUSIONS}

This paper used CAT to investigate the impacts of plantation forests on streamflow by utilising historic plantation history. Some of the key results of the paper were that:

- CAT was able to provide an adequate streamflow prediction over time. However, the model had a tendency to over-predict streamflow in the autumn/early winter period. Improvement in prediction over this period may be improved through connection of alluvial segments within a catchment to better account for gaining and losing water stores along a stream reach including dams and wetlands;

- Incorporation of the timing and pattern of plantation history demonstrated a small, consistent improvement in temporal streamflow predictions in each of the three catchments. The full impact of a 
Barlow et al., Capturing the lag and response in streamflow due to plantation history.

number of these plantations is yet to occur with the majority of current plantation plantings in the three catchments occurring over the last ten years;

- The modelling was able to demonstrate a delayed pattern (4-5 years) in streamflow response to the timing of plantation development. This is consistent with previous research into the effect of afforestation on streamflow (eg. Scott and Lesch, 1997; Scott and Prinsloo, 2008).

The application of CAT to a range of different scenarios (Marcar et al., 2010) has shown that the establishment of new plantations within the DEC catchment will have varying effects on streamflow depending on the location of new plantations, due to differences in a range of factors including climate, soil properties, slope and the proportion of land area that can be converted from pasture and crops to plantation forests. The ability to use CAT to investigate these impacts provides an additional tool for policy and catchment managers to use in informing, understanding and prioritizing land use change at the catchment scale.

\section{ACKNOWLEDGMENTS}

The authors of this paper would like to acknowledge the financial support of the CSIRO as well as the support of the Department of Primary Industries Victoria, the eWater CRC and the Future Farm Industries CRC which have enabled this research to be conducted. The authors would like to thank Don McGuire, ForestrySA for pulling together the land use history data for the DEC catchments.

\section{REFERENCES}

Arnold, J., Allen, P., 1999. Automated methods for estimating baseflow and ground water recharge from stream records. Journal of the American Water Resources Association 35, 411-424.

Brown, A.E., Podger, G.M., Davidson, A.J., Dowling, T.I., Zhang, L., 2007. Predicting the impact of plantation forestry on water users at local and regional scales: An example for the Murrumbidgee River Basin, Australia. Forest Ecology and Management 251, 82-93.

BRS, 2001. Land use mapping at catchment scale. Principles, procedures and definitions. Department of Agriculture Fisheries and Forestry and Bureau of Rural Science, Canberra, ACT.

Cheng, X., Benke, K.K., Beverly, C., Christy, B., Weeks, A., Barlow, K., Reid, M., 2013. Balancing tradeoff issues in land use change and the impact on streamflow and salinity management. Hydrological Processes, 10.1002/hyp.9698.

DPI, 2009. Models of the Catchment Analysis Tool (CAT1D version 32) August 2009 Future Farming Systems Research, Department of Primary Industries, Rutherglen, Australia.

Landsberg, J., Waring, R., 1997. A generalised model of forest productivity using simplified concepts of radiation-use efficiency, carbon balance and partitioning. Forest Ecology and Management 95, 209-228.

Marcar, N., Theiveyanathan, T., Roxburgh, S., Gilfedder, M., Littleboy, M., Almeida, A., Christy, B., Barlow, K., Crawford, D., Benyon, R., 2010. Methodology to assess site-specific impacts of plantations on catchment water yields., in: CSIRO: Water for a Healthy Country National Research Flagship (Ed.). CSIRO, p. 113.

Nash, J.E., Sutcliffe, J.V., 1970. River flow forecasting through conceptual models part I - A discussion of principles. Journal of Hydrology 10, 282-290.

Scott, D.F., Lesch, W., 1997. Streamflow responses to afforestation with Eucalyptus grandis and Pinus patula and to felling in the Mokobulaan experimental catchments, South Africa. Journal of Hydrology 199, 360-377.

Scott, D.F., Prinsloo, F.W., 2008. Longer-term effects of pine and eucalypt plantations on streamflow. Water Resources Research 44, doi: 10.1029/2007WR006781.

VWQMN, 2009. Victorian Water Resources Data Warehouse, http://www.vicwaterdata.net/vicwaterdata/home.aspx, Accessed Febuary 2009.

Weeks, A., Christy, B., Lowell, K., Beverly, C., 2008. The Catchment Analysis Tool: demonstrating the benefits of interconnected biophysical models., in: Pettit, C., Cartwright, W., Bishop, I., Lowell, K., Pullar, D., Duncan, D. (Eds.), Landscape Analysis and Visualisation. Springer-Verlag, Berlin, pp. 49-71. 